\title{
An investigation of ecological correlates with hand and foot morphology in callitrichid primates.
}

\begin{tabular}{|r|l|}
\hline Journal: & American Journal of Physical Anthropology \\
\hline Manuscript ID: & AJPA-2012-00419.R2 \\
\hline Wiley - Manuscript type: & Research Article \\
\hline Date Submitted by the Author: & n/a \\
\hline Complete List of Authors: & $\begin{array}{l}\text { Smith, Joanna; University of Worcester, Institute of Science and the } \\
\text { Environment } \\
\text { Smith, Andrew; Anglia Ruskin University, Life Sciences }\end{array}$ \\
\hline Key Words: & Monkeys, Limb morphology, Exudativory, Friction \\
\hline \multicolumn{2}{|l}{} \\
\hline
\end{tabular}


An investigation of ecological correlates with hand and foot morphology in callitrichid primates.

Joanna M. Smith ${ }^{1}$, Andrew C. Smith ${ }^{2}$

${ }^{1}$ Institute of Science and the Environment, University of Worcester, Worcester WR2 6AJ, UK.

${ }^{2}$ Animal and Environmental Research Group, Department of Life Sciences, Anglia Ruskin University, Cambridge CB1 1PT, UK

36 pages, 3 figures, 5 tables

Abbreviated title: Hand morphology and exudativory in callitrichids

Key words: Monkeys, Limb morphology, Exudativory, Friction

Contact author: Dr. Joanna Smith, ISE, University of Worcester, Worcester WR2 6AJ, UK. Tel: +44 (0) 1905542372 E-mail: joanna.smith@worc.ac.uk

John Wiley \& Sons, Inc. 


\begin{abstract}
Studies of primate taxomony and phylogeny often depend on comparisons of limb dimensions, yet there is little information on how morphology correlates and contributes to foraging strategies and ecology. Callitrichid primates are ideal for comparative studies as they exhibit a range of body size, limb proportions and diet. Many callitrichid species exhibit a high degree of exudativory and to efficiently exploit these resources they are assumed to have evolved morphologies that reflect a level of dependence on these resources. We tested assumptions by considering measurements of limb proportion and frictional features of the volar surfaces in preserved specimens of 25 species with relation to published life history and ecological data. The degree of exudativory and utilization of vertical substrates during foraging were found to correlate both with size and with size-corrected foot and hand dimensions. Smaller species, which engage in greater degrees of exudativory, had proportionally longer hands and feet and more curved claw-like tegulae (nails) on their digits to facilitate climbing on vertical substrates. The density of patterned ridges (dermatoglyphs) on the volar surfaces of the hands and feet is higher in more exudativorous genera, suggesting a role in climbing on vertical tree trunks during foraging. Dermatoglyph comparisons suggest that ridges on the soles and palms may facilitate food procurement by enhancing frictional grip during exudate feeding. Volar pad features corroborate taxonomic relationships described from dental morphology.
\end{abstract}


Callitrichidae (Mammalia: Primates) includes over forty diverse species of New World Monkey. These may be grouped into 'marmosets' (Callibella, Callimico, Callithrix, Cebuella, and Mico) or tamarins (Leontopithecus and Saguinus) (Rylands et al., 2012). Prior to the reassessment of taxonomic relationships by Rylands et al., (2000) and the subsequent recognition of Callibella as a separate species (Van Roosmalen and Van Roosmalen, 2003), Callithrix was the most diverse genus, with over twenty species. Since 2003 Callibella, Callimico and Cebuella have been considered monotypic and fourteen species have been removed from Callithrix to a new genus Mico, thereby making Saguinus the most diverse callitrichid genus (Rylands et al., 2012). Recent analysis of phylogenetic relationships in all primates (Perelman et al. 2011) further confirms the taxonomy described in Cortés-Ortiz (2009): (Saguinus (Leontopithecus (Callimico (Callithrix (Callibella (Cebuella/Mico)))))).

Although their taxonomy is under seemingly constant review, callitrichids are ideal subjects to investigate morphology and allometry trends in relation to ecology because they represent a wide range of body sizes and exhibit variability in diet and foraging strategies both between and within genera, despite close phylogenetic proximities.

Phylogeny and taxonomy of primates often depend on comparing limb proportions and morphology (i.e. Falsetti et al., 1993; Shoshani et al., 1996; Anderson et al., 2000; Schmidt, 2005, 2008). The relationships between primate locomotor modes (i.e. vertical clinging and leaping, quadrupedalism and bipedalism) and post-cranial morphology are well-known (e.g. Anenome, 1990; Gebo, 1996; Lemelin and Schmitt, 1998; Garber and Leigh, 2001; Anapol et al., 2005; Schmidt, 2005; Wright, 2007; Schmidt, 2008).

While diverse morphologically and ecologically, most callitrichids have a common trait of consuming plant exudates, principally gums (see Smith, 2010). Consequently, many species 
possess unique features that allow them to efficiently utilize this nutrition-poor, difficult to access resource including specialist digestive systems in Mico (Callithrix) emiliae (Ferrari and Martins, 1992), gouging incisors, and other craniofacial characteristics in Callithrix, Cebuella and Mico (Forsythe \& Ford, 2011). All callitrichids have elongated, laterally compressed and hooked claw-like nails or ‘tegulae’ (Garber, 1980, Thorndike, 1968; Soligo and Müller, 1999). Though originally considered a primitive character, it is now assumed that callitrichid tegulae are a derived specialization which facilitate the gum-feeding behavior prevalent in the marmosets and tamarins (Garber and Sussman, 1984; Sussman and Kinzey, 1984; Hamrick, 1998; Soligo and Müller, 1999). Garber et al. (1996) identified two major problems with this inference: firstly, although the presence of 'claws' may be expected to aid vertical clinging, the postural behavior most commonly associated with gum-feeding (Garber, 1992, 1993; Jackson, 2011), the link between gum-feeding and the presence of clawed digits has not been demonstrated across species with differing degrees of exudativory; secondly, despite the considerable variability in the extent to which callitrichids exploit gums, all possess tegulae. Garber et al. (1996) agree with Cartmill (1979) that the presence of tegulae is an adaptation which simply allows the family to exploit large-diameter vertical supports. Indeed recent studies suggest access to fungi growing on large-diameter substrates is a major consideration for some species (Porter and Garber, 2004; Hilário and Ferrari, 2010).

Studies on non-exudativorous climbing animals (e.g. birds (Pike and Maitland, 2004); lizards (Zani et al., 2000; Ribas et al., 2004; Tulli et al., 2009); carnivores (Van Valkenburgh, 1987)) from both arboreal and saxicolous (rocky) habitats, have demonstrated positive correlations between climbing and claw curvature. More frequent climbing behavior is contingent on a more strongly decurved claw geometry (i.e. Feduccia, 1993). Such findings may bolster suggestions that the presence of tegulae in the callitrichids is largely a result of 
climbing requirements per se rather than specifically to exudativory. This study will consider differences in tegulae in relation to the ecology of callitrichids in order to clarify the factors underlying the presence of claw-like nails in marmosets and tamarins.

Bicca-Marques (1999) examined hand dimensions in insectivorous callitrichids, and concluded that hand shape is driven by foraging technique, such that: generalist opportunists, gleaning insects and other food from tree trunks and leaf surfaces, had relatively short hands and manipulative foragers searching for insects within crevices had long, slender hands. However, because manipulative insect foraging often occurs on large vertical supports such as tree trunks (Sussman and Kinzey, 1984; Garber, 1992), it is difficult to dissociate the effects of climbing from those of insectivory. Long hands would increase the angle subtended by fingers and thumb when climbing on vertical supports to increase the effective grip on large diameter supports (Cartmill, 1985). Furthermore, postural behaviors such as vertical clinging and trunkto-trunk leaping, are strongly linked with exudativory and typical on these supports (Garber, 1993; Smith, 1997; Youlatos, 1999a; Garber et al., 2009; Youlatos, 2009). We consider whether intergeneric and interspecific differences in hand and foot morphology are influenced by diet and positional behavior.

A number of arboreal non-primates have patterned, ridged skin on the ventral surfaces of their hands and feet (e.g. tree shrews (Tupaia glis: Lemelin, 2000); common dormice (Muscardinus avellanarius: Haffner, 1998); raccoons (Procyon lotor: Munger and Pubols, 1972); Virginia opossums (Didelphus virginiana: Lemelin, 2000); feathertail gliders (Acrobates pygmaeus: Rosenberg and Rose, 1999) and koalas (Phasocolarctos cinereas: Henneberg et al., 1997)). Such patterns, referred to as dermatoglyphs, are also found in primates and are believed to serve two important functions: first, these patterns enhance the 
frictional grip in climbing (Cartmill, 1979; Hamrick, 1998; Lemelin and Jungers, 2007); and second they enhance tactile sensitivity, particularly when associated with the fingertips (Loesch and Martin, 1984; Dominy, 2004). Both functions are not mutually exclusive, indeed both are likely to be important to a climbing animal to assess the physical profile of the surfaces upon which they are moving to prevent slipping (Hoffman et al., 2004). The volar surface dermatoglyphs of callitrichid primates will be examined in consideration of the potential frictional role of epidermal patterning on volar surfaces during climbing and foraging.

Although a number of studies allude to relationships between morphology, positional behavior and exudate foraging in callitrichids, none have considered quantitative relationships with exudativory (Garber and Sussman, 1984; Garber, 1991, 1992, 1993; Bicca-Marques, 1999; Lemelin and Jungers, 2007). Nash and Burrows (2010), discussing the high degree of variability in exudate consumption by callitrichids, identified as an important gap in the current understanding the lack of interspecific morphological comparisons. We analyse data derived from published values in multiple field studies of foraging behaviour alongside morphological data from museum specimens to address this gap focusing on how hand and foot morphology relates to primate diet and food procurement using the Callitrichidae as a model. 


\section{METHODS}

Skins of 235 adult specimens from 25 species and six extant callitrichid genera (Table 1) were photographed (with a Fujifilm Finepix s5700) at the Natural History Museum, London. Photographs were taken of full pelts from ventral and dorsal perspectives, of the ventral and dorsal aspects of whole hands and feet, and of the tegulae and volar surfaces. To minimise parabolic effects, specimens were laid flat and all photographs were taken from directly above the specimen, at an angle perpendicular to the surfaces. Images were taken from a range of distances $(0.2-1.5 \mathrm{~m})$ with this distance dependent on the level of resolution necessary for the area of interest being photographed. Full pelts were photographed from $0.6-1.5 \mathrm{~m}$. To allow measurements to be made from the resultant images, $\mathrm{mm}$ grids printed onto clear acetate were placed centrally on the specimen for every individual image taken providing an image-specific calibration point for every photograph. No measurements were taken from the margins of the images.

Specimens used are recorded in the museum catalogue (Napier, 1976) and were wildcaught by a variety of natural history collectors from the early $19^{\text {th }}$ to late $20^{\text {th }}$ century. Current nomenclature was determined by cross-referencing the museum catalogue (Napier, 1976) with more recent systematics (Rylands et al. 2008; Rylands and Mettiermeier 2009). Skins identified in the catalogue as juveniles and those with no information about age but which were significantly below the normal published size ranges for the species were excluded. Data from individual specimens was only included if elements of morphology considered were measurable from the skins, as features in some were obscured by methods of skin preparation and general wear and tear. Specimens from which hand and foot measurements were made had bones still intact within the fingers and toes. This study aimed to extend potential uses of skins, which are a widely available museum resource, to allow direct comparisons of multiple 
morphological measures (including soft-tissue measurements) made from a single specimen. Differences between specimens in shrinkage, age and preparation techniques might be expected to introduce error, but analysis of a subset of specimens for which collection measurements of head-body length (HBL) and hindfoot length were available suggests that relative trends in data are unaffected by these. A full list of exact specimens used can be provided by the corresponding author on request.

The photographs taken were used to derive measurements for: HBL (distance measured from tip of nose to proximal base of the tail: Martin et al. 2001)); foot length (from back edge of heel to tip of longest toe: Martin et al. 2001); hand length (from proximal edge of palm to tip of longest finger) and of the longest finger (finger 3) and toe (toe 2) from base of digit to tip (these digits were selected for analysis due to their potential greater influence on prehensile ability, as suggested in Lemelin and Jungers, 2007). All image analyses were carried out using the free Java image processing program, ImageJ (Rasband, 2009).

For each individual, average density of dermatoglyphic ridges was determined from analysis of between five and eight images of $2 \mathrm{~mm} \times 2 \mathrm{~mm}$ sections of ventral surfaces of both the hand (palmar) and foot (plantar). Sections were cropped from photographs of palmar and plantar surfaces, using the calibration grid to standardize the size of each section. Ridge widths were measured using Image J and used to calculate average number of ridges per $\mathrm{mm}$ of hand/foot. Tegula curvature was determined via the method used by Pike and Maitland (2004) for quantification of claw 'hookedness' in raptorial and scansorial birds, and using the angle measuring tool in ImageJ. According to this method, a greater angle corresponds with a more 'hooked' tegula. 
An extensive literature search was conducted and data collated on several aspects of species ecology, including: percentage of time spent foraging on different food types, such as fruit, prey, and exudates; percentage of locomotory activity represented by scansorial (vertical climbing) activity and by trunk to trunk leaping; and size and orientation of supports utilized during foraging (Table 2). Studies were included if data was recorded from wild populations and where behaviours were being recorded from single-species troops. Where several studies had comparably collected/described data, average values were calculated. Data were collated from results in the following studies: Garber, $1980^{1}$; da Fonseca and Lacher, $1984^{2}$; Garber and Sussman, 1984³ ; Yoneda, 1984 a, b; Garber, 19885; Ayres and Clutton-Brock, $1992^{6}$; Egler, $1992^{7}$; Ferrari and Strier, $1992^{8}$; Garber, $1992^{9}$; Peres, $1992^{10}$; Rosenberger, $1992^{11}$; Garber, $1993^{12}$; Peres, $1993^{13}$; Lopes and Ferrari, $1994^{14}$; Peres, $1994^{15}$; Garber and Pruetz, $1995^{16}$; Ferrari and Digby, $1996^{17}$; Dietz et al., $1997^{18}$; Peres, $1997^{19}$; Garber, $1998^{20}$; Hamrick, $1998^{21}$; Youlatos, 1999a $\mathrm{a}^{22}$; Araújo et al., 2000²3 Corrêa et al., 2000²4; Heymann and Buchanan-Smith, $2000^{25}$; Heymann et al., 2000²6; Martins and Setz, 2000²7 Oliveira and Ferrari, 2000²8; Garber and Leigh, 2001 ${ }^{29}$; Miranda and Faria, 2001 ${ }^{30}$; Porter, 2001 ${ }^{31}$; Regan et al., 2001 ${ }^{32}$; Lehman, 2004 ${ }^{33}$; Porter, 2004 ${ }^{34}$; Poveda and Sanchez-Palomino, 2004 ${ }^{35}$; Raboy and Dietz, $2004^{36}$; Bicca-Marques, 2005 ${ }^{37}$; Garber et al., 2005 $5^{38}$; Yépez et al., 2005 ${ }^{39}$; Cunha et al., 2006 ${ }^{40}$; Burity et al., $2007^{41}$ a, b; da Silva and Ferrari, $2007^{42}$; de Castro and Araújo, $2007^{43}$; Digby et al., $2007^{44}$; Garber, $2007^{45}$; Lapenta and Procópio-de-Oliveira, 2008 ${ }^{46}$; Nadjafzadeh and Heymann, $2008^{47}$; Porter et al., 2007 ${ }^{48}$; Raboy et al., $2008^{49}$; Garber et al., 2009 ${ }^{50}$; Garber and Porter, $2009^{51}$; Porter et al., 2009 ${ }^{52}$; Rehg, 2009 ${ }^{53}$; Veracini, 2009 ${ }^{54}$; Youlatos, $2009^{55}$; Hilário and Ferrari, 2010 $0^{56}$; Porter and Garber, $2010^{57}$; Smith, $2010^{58}$. Superscript values indicate sources for each of the species as indicated in Table 2. 
Statistics were performed in SPSS Version 16.0. Morphological data for genera were compared either using ANOVA or Kruskal-Wallis tests (following tests for equality of variance). Post-hoc comparisons between genera were undertaken using Tukey or MannWhitney U tests. All post-hoc tests reported for differences between genera are significant at the $\mathrm{p}<0.05$ level.

John Wiley \& Sons, Inc. 


\section{RESULTS}

\section{Morphological correlates with body size}

Callitrichids show an approximate two-fold size range between the smallest (Cebuella pygmaea) and largest species (Saguinus leucopus) (Table 3). There are significant differences in mean HBL between genera (Table 4). Post-hoc Mann-Whitney U tests identified Cebuella as significantly smaller than all other genera and that Leontopithecus and Saguinus are significantly larger than Callithrix and Mico. This gives three distinct size categories of: 'small' (Cebuella); 'medium' (Callithrix and Mico) and 'large' (Callimico, Saguinus and Leontopithecus).

Proportional hand lengths were similar between differently sized species (Table 3). Rates of increase in hand $\left(\mathrm{HBL}^{0.73}\right)$ and finger length $\left(\mathrm{HBL}^{0.73}\right)$ between species, although reduced, are not significantly different from isometric expectations (Table 5: difference from slope of 1: $\mathrm{t}_{\text {hand }}=1.30,48$ d.f., N.S.; $\mathrm{t}_{\text {finger }}=1.09,48$ d.f., N.S.). There are significant differences between genera in proportional hand length and finger length (Table 4). Post-hoc Tukey and MannWhitney U tests identify that differences in forelimb dimensions result from Leontopithecus having significantly longer fingers and hands than Callithrix, Cebuella, Mico and Saguinus.

Hindlimb dimensions show smaller species have proportionally longer feet and toes than larger species (Table 3). Foot length and toe length both increase as $\mathrm{HBL}^{0.65}$ between species, at a rate significantly less than isometric expectations (Table 5: difference from slope of $1: t_{\text {foot }}$ $=2.48,46$ d.f., $\mathrm{p}<0.05 ; \mathrm{t}_{\mathrm{toe}}=2.44,46$ d.f., $\left.\mathrm{p}<0.05\right)$. There are significant differences between genera (Table 4) in both proportional foot length and proportional toe length. Post-hoc Tukey tests identify that these resulted from differences in Saguinus, which had significantly shorter feet and toes than Callithrix, Cebuella or Leontopithecus. 
In $18 / 25(72 \%)$ species the palmar ridge density was greater than the plantar density (Table 3 ) with this trend being statistically significant for seven species (paired t-tests: . jacchus, $\mathrm{t}=$ 3.06, 15 d.f., $\mathrm{p}<0.05 ;$ C. penicillata $, \mathrm{t}=-3.98,17$ d.f., $\mathrm{p}=0.001 ;$ M. humeralifer $, \mathrm{t}=-4.63,3$ d.f., $\mathrm{p}<0.05 ;$ S. fuscicollis, $\mathrm{t}=-6.22,42$ d.f., $\mathrm{p}<0.001 ; S$. geoffroyi, $\mathrm{t}=-3.69,4$ d.f.; $S$. mystax, $\mathrm{t}=-2.24,17$ d.f.,; S. nigricollis, $\mathrm{t}=-2.57,11$ d.f., $\mathrm{p}<0.05$ for all). There was a marginally non-significant negative trend between body size (HBL) and palmar ridge density across all species though a significant negative correlation with size occurs with plantar ridge density (Table 5). At genus-level, palmar ridge densities are significantly greater than plantar ridge densities (Figure 1) in both Callithrix (paired t-test: $\mathrm{t}=4.12,36$ d.f., $\mathrm{p}<0.001$ ) and Saguinus (paired t-test: $\mathrm{t}=-6.00,119$ d.f., $\mathrm{p}<0.001$ ).

There are significant differences between genera in both palmar ridge densities and plantar ridge densities (Table 4 and Figure 1). Post-hoc Tukey tests identify that Callimico, Saguinus and Leontopithecus have significantly lower palmar ridge densities than Callithrix, Cebuella or Mico. Callimico and Saguinus have significantly lower plantar ridge densities than Cebuella, Callithrix or Mico (Figure 1). There are significant differences in palmar ridge densities within Callithrix (ANOVA: $\mathrm{F}_{3,33}=6.20, \mathrm{p}<0.005$ ), with $C$. aurita and C. flaviceps having significantly lower palmar ridge densities than C. jacchus or C. penicillata. There were also significant differences in palmar ridge densities for Saguinus species (ANOVA: $F_{11,109}=3.50$, $\mathrm{p}<0.001$ ), as a result of higher palmar ridge densities in $S$. bicolor.

There is an inverse relationship between tegula curvature and body size such that smaller species have more hooked tegulae (Table 5). Genus-level differences in tegula shape are significant (Table 4), though post-hoc tests do not identify the locations of significant 
differences. Significant differences are noted in tegula curvature between the species within Callithrix (ANOVA: $\mathrm{F}_{3,25}=4.96, \mathrm{p}<0.01$ ). Post-hoc testing reveals that $C$. jacchus have significantly more curved tegulae than the less exudativorous C. flaviceps. Differences in tegula curvature (ANOVA: $\mathrm{F}_{10,72}=2.27, \mathrm{p}<0.05$ ) were also demonstrated within Saguinus resulting from increased tegula curvature in S. leucopus and S. martinsi.

\section{Morphological correlates with ecology}

Smaller species exhibit a greater degree of exudativory, scansorial activity and use of vertical supports when foraging (Table 5). Species that use vertical supports to a greater extent during foraging have proportionally longer feet (Fig. $2 \mathrm{~A}: \mathrm{R}=0.96, \mathrm{y}=10.45 \mathrm{x}-1.86,5$ d.f., $\mathrm{p}<0.005$ ) and more curved tegulae (Fig. $2 \mathrm{~B}: \mathrm{R}=0.82, \mathrm{y}=0.61 \mathrm{x}-1.05,5$ d.f., $\mathrm{p}=0.05$ ). Species utilising more trunk-to-trunk leaping have longer hands $(\mathrm{R}=0.92, \mathrm{y}=13.31 \mathrm{x}-2.01,6$ d.f., $\mathrm{p}<$ $0.005)$. More exudativorous species show greater degrees of scansorial activity $(\mathrm{R}=0.89, \mathrm{y}=$ $2.01 \mathrm{x}-0.11,6$ d.f., $\mathrm{p}<0.01)$ but there were no demonstrable species-level morphological correlates with exudativory. More exudativorous genera have a non-significant tendency towards increased palmar ridge densities (Fig 3A: $\mathrm{R}=0.75,5$ d.f., N.S.) and a significant increase in plantar ridge densities (Fig. 3B: $\mathrm{R}=0.83, \mathrm{y}=1.62 \mathrm{x}+3.87,5$ d.f., $\mathrm{p}<0.05$ ). No correlations with palmar or plantar ridge density were found with either frugivory or prey capture. 


\section{DISCUSSION}

Measurements from callitrichids in this study suggest that while relative proportions of the hands were conserved with respect to size, in general, all contributory elements of the feet were proportionally longer in smaller species. Smaller species of callitrichid exhibited greater degrees of exudativory. Consequently, it is to be expected that smaller species will also exhibit behaviors linked more frequently with exudativory, such as scansorial locomotion and use of vertical substrates. Given the greater reliance on exudativory in small species, an increase in relative proportions of the hind feet may confer more support when climbing vertical substrates. Norberg's (1986) evaluation of vertical climbing in the Eurasian tree creeper, Certhia familiaris, discusses how lengthening the foot reduces the forces necessary to maintain a grip on a vertical trunk. Furthermore, increasing the length of the foot would act to increase the effective grip while climbing, even without the additional benefit of 'claws' (Cartmill, 1985).

Arboreal primates have unique hand proportions and in particular possess relatively elongated fingers with a greater capacity for prehensility (Kirk et al., 2008). This feature of primates is usually explained as an adaptation to locomotion on small branches, allowing them to create a secure surrounding grip on narrow diameter branches and vines (Lemelin, 1999). As the fingers can bear a significant portion of the weight during locomotion, and since stresses on a digit are suggested to increase in direct proportion to length, expectations are that with increasing size, species should have adaptations for reducing the stress on these digits, such as shortening the functional length (Krakauer et al., 2002) or increasing development of broad, thickened cushion-like pads (described for arboreal rodents in Haffner, 1998). Lemelin and Jungers (2007) study of hand proportions in thirty species of strepsirrhines noted that as body size increases, toes and fingers become proportionally shorter. Such trends may mean that the ability to fully enclose wider diameter branches in an encircling grip is reduced in larger 
However, long, prehensile fingers in primates are also implicated in a greater ability to manipulate objects (Lemelin, 1999). Specialist manipulative foragers such as Leontopithecus have longer, narrower hands than other callitrichid genera (Bicca-Marques, 1999), linked to their strategy of foraging in crevices such as bromeliads and tree holes (Dietz et al., 1997). The present study also found that Leontopithecus had significantly longer hands (and fingers) than Callithrix, Cebuella, Mico and Saguinus. Saguinus has proportionally shorter hands than other genera. This was in concordance with Bicca-Marques (1999) who separates Saguinus into three groups according to hand shape: those with long, narrow hands (S. fuscicollis, S. nigricollis, $S$. tripartitus); those with intermediate shaped hands (S. bicolor, S. geoffroyi, S. leucopus, $S$. midas, S. oedipus) and those with short, wide hands (S. labiatus, S. mystax). He suggested that long, narrow hands were related to manipulative foraging for insects. The results of the present study broadly supported these groupings, manipulatively foraging species $S$. fuscicollis, $S$. nigricollis and S. tripartitus (Heymann and Buchanan-Smith, 2000), have long hands compared with many congeners and consumed greater proportions of animal prey.

Stephenson et al.'s (2010) study of comparative hand morphology noted a diversity of claw shapes in galagos, and they suggest that the observed gradient from nail to claw may be evidence of an evolutionary response to allow exploitation of large diameter supports for 
exudativory. However, their study did not present any quantitative analysis of either claw curvature or exudativory levels. There is evidence from the present study that exudativory and scansorial activity are correlated, and scansorial species which utilize vertical supports to a greater degree have more hooked tegulae. Youlatos (1999b) examined the positional behavior of six sympatric Ecuadorian primates and also found that small tegulae-bearing callitrichids showed the highest proportions of large vertical support use. This was attributed to requirements for exudativory but, again, no values are given for the proportion of exudates in the different species' diets, supporting only observations in Garber et al. $(1996 ; 2009)$ that the presence of tegulae in callitrichids is linked to vertical foraging behavior. The advantages of claws and claw-like nails in vertical substrate foraging was suggested to be of particular importance for smaller-bodied species that regularly utilize vertical, large-diameter surfaces, where they facilitate extra grip to compensate for limbs which have too short a reach to allow an effective contact angle to be subtended (Soligo and Martin, 2006; Jackson, 2011).

Bock \& Miller (1959) describe how the curvature of the scansorial claw in woodpeckers is key in allowing the tip of the claw to penetrate into the bark of tree trunks. The current study found no direct link between the degree of exudativory and tegula curvature between species, though as seen in Youlatos (1999b), smaller (and more exudativorous) species did have more hooked tegulae. The more exudativorous species of Callithrix exhibit greater tegula curvature, trends which are not observed within Saguinus. While Saguinus are opportunist exudativores, Callithrix are specialists with procumbent incisors to gouge and wound the trees to instigate exudate production. To do this, Callithrix jacchus anchor themselves using their upper incisors and then gouge upwards with their lower jaw, which is capable of producing an upwardly directed force equivalent to eight times their own body weight to dig into the tree trunk (Vinyard et al. 2009). Having tegulae with a greater curvature might be expected to increase 
interlocking capability with the rough bark substrate, and further help to anchor the monkeys to increase stability on vertical substrates while engaged in gum-feeding. Further, proportionally larger feet in the more exudativorous species, combined with better attachment to the substrate could provide improved leverage to increase gouging efficiency.

Hamrick (2001) found that the breadths of papillary ridges on the toes of didelphid marsupials were wider than on the fingers, i.e. ridge density was greater on the hands. Based on the importance of the hands in tactile exploration, he argued that the increased density of ridges on the hand serves a primarily sensory purpose via an increased distribution of mechanoreceptors. It might be expected, if the key function of ridges on the volar skin is sensory, that ridge density will be higher on the hands. In the majority of callitrichid species, ridge densities were higher on the hands than on the feet, lending support to the hypothesis that dermatoglyphic ridges have a function in improving touch discrimination. Such a role would be particularly important to frugivorous primates, that judge fruit ripeness using a combination of cues, including palpating fruit with the hand (Dominy, 2004). Hoffman et al.'s (2004) study of the fingerprints of nine primate species found a positive correlation between the density of sensory cells and frugivory yet the present study found no correlations between frugivory and palmar or plantar ridge densities, although the genera with the lowest values for palmar ridge density here are chiefly frugivorous, perhaps reducing the argument for a chiefly sensory role.

Most primates have greater hindlimb than forelimb contact time when climbing on arboreal supports (Cartmill et al., 2002), so if the purpose of volar skin patterning were to increase friction, as suggested by Haffner's (1998) exploration of the microanatomy of the foot pads of arboreal rodents, it might be expected that ridge densities would be greater on plantar rather than palmar surfaces. On this evidence, the present study's results contradict a frictional 
role for dermatoglyphic ridges. However, comparative studies of walking biomechanics have found that, unlike most primates, C. jacchus exhibits relatively greater forelimb forces and contact duration when walking (Young, 2009), galloping (Hanna et al., 2006) and climbing (Schmitt, 2003). Cartmill et al. (2002) link longer hindlimb contact to the necessity to maintain a firm grasp on thin flexible supports and, as callitrichids utilize forelimb-powered vertical climbing on large diameter substrates to a significant extent (Hunt et al., 1996), increased frictional contact of the forelimb might be of greater importance. Understanding of the potential frictional role of palmar and plantar ridges in vertical climbing would significantly benefit from consideration of biomechanics of locomotion in other callitrichids. As other vertical climbers, such as the lorises (Loris and Nycticebus), also exhibit atypical impact forces (Schmitt and Lemelin, 2004), the study of comparative hand/foot dermatoglyphs in primates with typical and atypical gaits and forelimb vs. hindlimb powered climbing would be desirable.

The influence of other locomotor modes on the expression of plantar and palmar dermatoglyphs, may be a key consideration. Although callitrichids are often categorized as generalist arboreal quadrupeds (Connour et al., 2000) evidence from the literature suggests many species utilize leaping locomotion to a significant extent. Observational and biomechanical studies find that jumping in Saguinus, Callimico, Callithrix and Cebuella is characterized by hindlimb-driven takeoff and forelimb-first landing (Garber, 1991; Garber et al., 2009). It is therefore likely that the forelimbs act to absorb the shock of landing impact in callitrichids (Garber and Leigh, 2001), and will form the initial frictional contact with a substrate to counter slipping. This perhaps provides a further explanation of the increased density of dermatoglyphic ridges on the palms of the hands in comparison to the soles of the feet and potentially also the proportionally longer hands seen in callitrichids which more commonly engage in trunk to trunk leaping in this study. It would be of interest to consider 
comparative dermatoglyphs in specialist leaping primates such as indrids and lemurs, which are well studied in terms of jumping biomechanics (Crompton et al., 1993; Demes et al., 1996, 2005), and which land hindlimb-first, to see if patterns in volar skin pattern are reversed.

Smith (2010) suggests generic differentiation in terms of dental specializations for gouging should predict Cebuella and Callithrix are the most exudativorous, Saguinus, Leontopithecus and Callimico the least with Mico intermediate between the two groups. These expectations are borne out by trends for generic exudate consumption in this study. As there were generic-level correlations between ridge densities on hands and feet and exudativory, ridge density values predict exudativory in a similar way to dental specialization. Significant differences in palmar and plantar ridge densities result from Callimico, Leontopithecus and Saguinus forming a distinct and separate group from Callithrix, Cebuella and Mico.

According to dental adaptations for gouging, Callithrix may be further split into three groups (re Natori and Shigehara, 1992): (a) C. jacchus and C. penicillata; (b) C. kuhli and C. geoffroyi; C. aurita and (c) C. flaviceps, in order of decreasing exudativory (Smith, 2010). Our results for palmar ridge densities largely support these groupings of $C$. jacchus and $C$. penicillata with similar values to one another for palmar ridge density, as do C. aurita and C. flaviceps. Furthermore, C. aurita and C. flaviceps both have significantly lower palmar ridge densities than either $C$. jacchus or C. penicillata. As discussed earlier, tegula curvature is higher in more exudativorous species within this genus, suggesting that ridge density probably has a greater role in gripping, driven by exudate feeding requirements, than in sensory assessment of fruit ripeness. This demonstrates the need for careful consideration of the various facets of a species' ecology which may influence morphology. 
Callimico, although genetically closer to Callithrix, Cebuella and Mico than to Saguinus and Leontopithecus (Pastorini et al., 1998; Chaves et al., 1999) would not be recognized as such based on dental morphology alone. Callimico have not only retained the third molar, a dental feature typically absent from all other callitrichids (Cortés-Ortiz, 2009), but also do not exhibit the specialist incisors typical of the 'gouging' marmosets (see Hill, 1959; Forsythe and Ford, 2011) with which they are a close sister group. The relative morphology of volar surfaces in Callimico were similarly problematic and confirmed the difficult-to-resolve position of this genus within the Callitrichidae, ridge densities on both hands and feet suggested they were significantly different from both the marmosets and the tamarins.

To conclude, results suggest that the potential role of volar skin morphology and tegula curvature in the facilitation of exudativory bears further investigation. This is particularly desirable as differences in both reflect trends in dental morphology with relation to levels of exudativory, perhaps via similar evolutionary pressures related to food procurement and food handling. Furthermore, trends in hand and foot dermatoglyph density appeared to group species according to current taxonomy, aligning Saguinus with Leontopithecus and Mico with Callithrix and Cebuella corroborating the very early tenet of Biegert (1963) who considered the relationship of Callimico within the Callitrichidae, argued that combinations of 'cheridial' characters, (features of the hands/feet), including 'claw' presence and extent of frictional volar skin were better taxonomic indicators than dental morphology. Although, it would be difficult to argue based on our findings, that cheridial characters are stronger indicators than dental morphology, the undoubted importance of the role of hand and foot morphology in facilitating food procurement in the callitrichids certainly indicates this warrants further consideration, particularly with respect to differences in reliance on exudativory between species. 


\title{
ACKNOWLEDGMENTS
}

\author{
Thanks to Louise Tomsett, Curator of Mammals at the Natural History Museum for \\ arranging access to specimens and for all her help and to Philip Pugh for comments on an \\ earlier version of the manuscript. Both authors would also like to acknowledge Isobel \\ Stephenson, Stephen Bearder, Guiseppe Donati and Johann Karlson whose presentation at the \\ IPS Edinburgh 2008 sparked an interest in the topic. JMS would additionally like to thank Dan \\ Thornham, for helpful discussions about statistics and climbing. Finally, the authors are \\ grateful for the comments of the two anonymous reviewers whose constructive comments \\ helped clarify the message of this paper.
}

John Wiley \& Sons, Inc. 


\section{REFERENCES}

Anapol F, Turner TR, Mott CS, Jolly CJ. 2005. Comparative postcranial body shape and locomotion in Chlorocebus aethiops and Cercopithecus mitis. Am J Phys Anthropol 127: 231239.

Anderson MJ, Ambrose L, Bearder SK, Dixon AF, Pullen S. 2000. Intraspecific variation in the vocalizations and hand pad morphology of Southern Lesser Bush Babies (Galago moholi): A comparison with G. senegalensis. Int J Primatol 21 (3): 537-555.

Araújo A, Arruda MF, Alencar AI, Albuquerque F, Nascimento MC, Yamamoto ME. 2000. Body weight of wild and captive Common Marmosets (Callithrix jacchus). Int J Primatol 21 (2): 317-324.

Ayres JM, Clutton-Brock TH. 1992. River boundaries and species range size in Amazonian primates. Am Nat 140 (3): 531-537.

Bicca-Marques JC. 1999. Hand specialization, sympatry, and mixed-species associations in callitrichines. J Hum Evol 36 (4): 349-378.

Bicca-Marques JC. 2005. The win-stay rule in foraging decisions by free-ranging titi monkeys (Callicebus cupreus cupreus) and tamarins (Saguinus imperator imperator and Saguinus fuscicollis weddelli). J Comp Psychol 119(3): 343-351.

Biegert J. 1963. The evaluation of characteristics of the skull, hands and feet for primate taxonomy. In: Washburn SL. (Ed.) Classification and Human Evolution, Aldine Publishing Co. Chicago, USA. p 116-145.

Bock WJ, Miller WD (1959) The Scansorial Foot of the Woodpeckers, with Comments on the Evolution of Perching and Climbing in Birds. Am Mus Nov 1931 46pp.

Burity CHF, Cruz LD, Rocha VL, da Conceição NB, da Luz DE, da Silva Santos D, da Costa Campos D, Pissinatti A. 2007a. Golden Lion Tamarins, Leontopithecus rosalia 
(Linnaeus, 1766) in the Taquara Municipal Natural Park (Duque de Caxias, RJ): A Southern extension of the known range. Neotrop Primates 14 (1): 30-31.

Burity CHF, Pissinatti A, de Souza AM. 2007b. Morphometry and allometry of outer body in three species of the genus Callithrix Erxleben 1777 (Callitrichidae, Primates). Revista Brasileira de Zoociências 9 (2): 177-184.

Cartmill M, Lemelin P, Schmitt D. 2002. Toward a predictive theory of symmetrical gaits. Zool J Linn Soc 13: 401-420.

Cartmill M. 1979. The volar skin of primates: Its frictional characteristics and their functional significance. Am J Phys Anthropol 50: 497-510.

Cartmill M. 1985. Climbing. In: Hildebrand M. et al. (Eds) Functional Vertebrate Morphology Harvard University Press, London, UK. p 73-88.

Chaves R, Sampaio I, Schneider MP, Schneider H, Page SL, Goodman M. 1999. The place of Callimico goeldii in the callitrichine phylogenetic tree: Evidence from von Willebrand factor gene intron II sequences. Mol Phylogenet Evol 13 (2): 392-404.

Connour JR, Glander K, Vincent F. 2000. Postcranial adaptations for leaping in primates. J Zool 251: 79-103.

Corrêa HKM, Coutinho PEG, Ferrari SF. 2000. Between-year differences in the feeding ecology of highland marmosets (Callithrix aurita and Callithrix flaviceps) in southeastern Brazil. J Zool 2525: 421-427.

Cortés-Ortiz L. 2009. Molecular phylogenetics of the Callitrichidae with an emphasis on the marmosets and Callimico. In: The Smallest Anthropoids: The Marmoset/Callimico Radiation: 3-24. Ford SM, Porter L, Davis LC (Eds). New York, NY: Springer.

Crompton RH, Sellers WI, Gunther MM. 1993. Energetic efficiency and ecology as selective factors in the saltatory adaptation of prosimian primates. Proc Roy Soc B 254: 41-45. 
Cunha AA, Vieira MV, Grelle CEV. 2006. Preliminary observations on habitat, support use and diet in two non-native primates in an urban Atlantic forest fragment: The capuchin monkey (Cebus sp.) and the common marmoset (Callithrix jacchus) in the Tijuca forest, Rio de Janeiro. Urban Ecosystems 9: 351-359.

da Fonseca GAB, Lacher TE. 1984. Exudate-feeding by Callithrix jacchus penicillata in semideciduous woodland (Cerradão) in central Brazil. Primates 25 (4): 441-449.

da Silva SSB, Ferrari SF. 2007. Notes on the reproduction, behaviour and diet of Saguinus niger (Primates: Callitrichidae) in a forest remnant at the National Primate Centre, Ananindeua, Para. Biologia Geral e Experimental 7 (1): 19-28.

de Castro CS, Araújo A. 2007. Diet and feeding behaviour of Marmoset, Callithrix jacchus. Revista Brasileira de Ecologia 14-19

Demes B, Franz TM, Garlson KJ. 2005. External forces on the limbs of jumping lemurs at takeoff and landing. Am J Phys Anthropol 128: 348-358.

Demes B, Jungers WL, Fleagle JG, Wunderlich RE, Richmond BG, Lemelin P. 1996. Body size and leaping kinematics in Malagasy vertical clingers and leapers. J Hum Evol 31: $367-388$.

Dietz JM, Peres CA, Pinder L. 1997. Foraging ecology and use of space in wild golden lion tamarins (Leontopithecus rosalia). Am J Primatol 41(4): 289-305.

Digby LJ, Ferrari SF, Saltzman W. 2007. Callitrichines: The role of competition in cooperatively breeding species. In: Campbell CJ et al. (Eds) Primates in Perspective. Oxford University Press, Oxford, UK.

Dominy NJ. 2004. Fruits, fingers, and fermentation: The sensory cues available to foraging primates. Integr Comp Biol 44: 295-303.

Egler SG. 1992. Feeding ecology of Saguinus bicolor bicolor (Callitrichidae: Primates) in a relict forest in Manaus, Brazilian Amazonia. Folia Primatol 59: 61-76. 
Falsetti AB, Jungers WL, Cole TM. 1993. Morphometrics of the Callitrichid forelimb: A case study in size and shape. Int J Primatol 14 (4): 551-572.

Feduccia, A. 1993. Evidence from claw geometry indicating arboreal habits of Archaeopteryx. Science 259 (5096), 790-793.

Ferrari SF, Digby LJ. 1996. Wild Callithrix groups: Stable extended families? Am J Primatol 38: 19-27.

Ferrari SF, Martins ES. 1992. Gummivory and gut morphology in two sympatric callitrichids (Callithrix emiliae and Saguinus fuscicollis weddelli) from western Brazilian Amazonia. Am J Phys Anthropol 88 (1) 97-103.

Ferrari SF, Strier KB. 1992. Exploitation of Mabea fistulifera nectar by marmosets (Callithrix flaviceps) and muriquis (Brachyteles arachnoides) in south-east Brazil. J Trop Ecol 8 (3): 225-239.

Forsythe EC, Ford SM. 2011. Craniofacial adaptations to tree-gouging among marmosets. Anat Rec 294: 2131-2139.

Garber PA, Blomquist GE, Anzenberger G. 2005. Kinematic analysis of trunk-to-trunk leaping in Callimico goeldii. Int J Primatol 26 (1): 223-239.

Garber PA, Leigh SR. 2001. Patterns of positional behavior in mixed-species troops of Callimico goeldii, Saguinus labiatus, and Saguinus fuscicollis in northwestern Brazil. Am J Primatol 54 (1): 17-31.

Garber PA, Porter LM. 2009. Trunk-to-trunk leaping in wild Callimico goeldii in Northern Bolivia. Neotrop Primat 16 (1): 9-14.

Garber PA, Pruetz JD. 1995. Positional behavior in Moustached Tamarin monkeys: effect of habitat on locomotor variability and locomotor stability. J Hum Evol 28: 411-426. 
Garber PA, Rosenberger AL, Norconk MA. 1996. Marmoset misconceptions. In: Norconk MA et al. (Eds) Adaptive radiations of Neotropical Primates. Plenum Press, New York, USA. p 87-95.

Garber PA, Sallenave A, Blomquist GE, Anzberger G. 2009. A comparative study of the kinematics of trunk-to-trunk leaping in Callimico goeldii, Callithrix jacchus, and Cebuella pygmaea. In: Ford SM et al. (Eds.) The Smallest Anthropoids, Developments in Primatology: Progress and Prospects. Springer, NY, USA.

Garber PA, Sussman RW. 1984. Ecological distinctions between sympatric species of Saguinus and Sciurus. Am J Phys Anthropol 65: 135-146.

Garber PA. 1980. Locomotor behavior and feeding ecology of the Panamanian Tamarin (Saguinus oedipus geoffroyi, Callitrichidae, Primates). Int J Primatol 1 (2): 185-201.

Garber PA. 1988. Diet, foraging patterns, and resources defense in a mixed species troop of Saguinus mystax and Saguinus fuscicollis in Amazonian Peru. Behaviour 105(1-2): 18-34.

Garber PA. 1991. A comparative study of positional behavior in three species of tamarin monkeys. Primates 32 (2): 219-230.

Garber PA. 1992. Vertical clinging, small body size, and the evolution of feeding adaptations in the Callitrichinae. Am J Phys Anthropol 88: 469-482.

Garber PA. 1993. Feeding ecology and behaviour of the genus Saguinus. In: Rylands AB (Ed) Marmosets and Tamarins: Systematics, Behaviour and Ecology. Oxford University Press, Oxford, UK

Garber PA. 1998. Within- and between-site variability in Moustached Tamarin (Saguinus mystax) positional behaviour during food procurement. In: Strasser E et al. (Eds) Primate Locomotion: Recent Advances. Plenum Press New York, USA. p 61-78

Garber PA. 2007. Primate locomotor behaviour and ecology. In: Campbell, C.J. et al. (Eds) Primates in Perspective. Oxford University Press, Oxford, UK 
Gebo DL. 1996. Climbing, brachiation and terrestrial quadrupedalism: Historical precursors of hominid bipedalism. Am J Phys Anthropol 101: 55-92.

Haffner M. 1998. A comparison of the gross morphology and micro-anatomy of the foot pads in two fossorial and two climbing rodents (Mammalia). J Zool 244: 287-294.

Hamrick MW. 1998. Functional and adaptive significance of primate pads and claws: Evidence from New World anthropoids. Am J Phys Anthropol 106 (2): 113-127.

Hamrick MW. 2001. Morphological diversity in digital skin microstructure of didelphid marsupials. J Anat 198 (6): 683-688.

Hanna JB, Polk JD, Schmitt D. 2006. Forelimb and hindlimb forces in walking and galloping primates. Am J Phys Anthropol 130: 529-535.

Henneberg M, Lambert KM, Leigh C. 1997. Fingerprint homoplasy: koalas and humans. naturalScience (1). Available at: http://naturalscience.com/ns/articles/01-04/ns_hll.html

Heymann EW, Buchanan-Smith HM. 2000. The behavioural ecology of mixed-species troops of callitrichine primates. Biol Rev 75: 169-190.

Heymann EW, Knogge C, Tirado Herrera ER. 2000. Vertebrate predation by sympatric tamarins, Saguinus mystax and Saguinus fuscicollis. Am J Primatol 51(2): 153-158.

Hilário, R.R., Ferrari, S.F. 2010. Feeding ecology of a group of Buffy-Headed Marmosets (Callithrix flaviceps): Fungi as a preferred resource. Am J Primatol 72: 515-521.

Hill WCO. 1959. The anatomy of Callimico goeldii (Thomas) Trans Am Phil Soc 49 (5): 1-116.

Hoffman JN, Montag AG, Dominy NJ. 2004. Meissner corpuscles and somatosensory acuity: The prehensile appendages of primates and elephants. Anat Rec 281A: 1138-1147.

Hunt KD, Cant JGH, Gebo DL, Rose MD, Walker SE, Youlatos D. 1996. Standardized descriptions of primate locomotor and postural modes. Primates 37 (4): 363-387. 
Jackson CP (2011) The positional behaviour of pygmy marmosets (Cebuella pygmaea) in northwestern Bolivia. Primates 52 (2): 171-178.

Kirk EC, Lemelin P, Hamrick MW, Boyer DM, Bloch JI. 2008. Intrinsic hand proportions of euarchontans and other mammals: Implications for the locomotor behavior of plesiadapiforms. J Hum Evol 55: 278-299.

Krakauer E, Lemelin P, Schmitt D. 2002. Hand and body position during locomotor behavior in the Aye-Aye (Daubentonia madagascariensis). Am J Primatol 57: 105-118.

Lapenta MJ, Procópio-de-Oliveira P. 2008. Some aspects of seed dispersal effectiveness of golden lion tamarins (Leontopithecus rosalia) in a Brazilian Atlantic forest. Tropical Conservation Science 1(2): 122-139.

Lehman SM. 2004. Biogeography of the primates of Guyana: Effects of habitat use and diet on geographic distribution. Int J Primatol 25 (6): 1225-1242.

Lemelin P, Jungers WL. 2007. Body size and scaling of the hands and feet of prosimian primates. Am J Phys Anthropol 133 (2): 828-840.

Lemelin P, Schmitt D. 1998. The relation between hand morphology and quadrupedalism in primates. Am J Phys Anthropol 105 (2): 185-197.

Lemelin P. 1999. Morphological correlates of substrate use in didelphid marsupials: implications for primate origins. J Zool 165-175.

Lemelin P. 2000. Micro-anatomy of the volar skin and interordinal relationships of primates. J Hum Evol 38: 257-267.

Loesch DZ, Martin NG. 1984a. Finger ridge patterns and tactile sensitivity. Ann Hum Biol 11 (2): 113-124.

Lopes MA, Ferrari SF. 1994. Foraging behavior of a tamarin group (Saguinus fuscicollis weddelli) and interactions with marmosets (Callithrix emiliae). Int J Primatol 15 (3): 373-387. 
Martins MM, Setz EZF. 2000. Diet of Buffy Tufted-Eared Marmosets (Callithrix aurita) in a forest fragment in Southeastern Brazil. Int J Primatol 21 (3): 467-476.

Martin RE, Pine RH, DeBlase AF. 2001. A manual of mammalogy with keys to the families of the world. McGraw Hill, Boston US.

Miranda GHB, Faria DS. 2001. Ecological aspects of Black-pincelled Marmoset (Callithrix penicillata) in the cerradao and dense cerrado of the Brazilian Central Plateau. Braz J Biol 61 (3): 397-404.

Munger BL, Pubols LM. 1972. The sensorineural organization of the digital skin of the raccoon. Brain Behav Evol (5): 367-379.

Nadjafzadeh MN, Heymann EW. 2008. Prey foraging of red titi monkeys, Callicebus cupreus, in comparison to sympatric tamarins, Saguinus mystax and Saguinus fuscicollis. Am J Phys Anthropol 135(1): 56-63.

Napier PH. 1976. Catalogue of Primates in the British Museum (Natural History). I. Families Callitrichidae and Cebidae. British Museum (Natural History), London, UK. p 5-33.

Nash LT, Burrows AM. 2010. Advances and remaining sticky issues in the understanding of exudativory in primates In: Burrows A, Nash L. (Eds) The Evolution of Exudativory in Primates, Developments in Primatology: Progress and Prospects. Springer, NY, USA. p 1-23.

Natori M, Shigehara N. 1992. Interspecific differences in lower dentition among EasternBrazilian marmosets. J Mammal 73 (3): 668-671.

Norberg, RÅ. 1986. Treecreeper climbing mechanics, energetics and structural adaptations. Ornis Scand 17: 191-209.

Oliveira ACM, Ferrari SF. 2000. Seed dispersal by black-handed tamarins, Saguinus midas niger (Callitrichinae, Primates): Implications for the regeneration of degraded forest habitats in eastern Amazonia. J Trop Ecol 16(5): 709-716. 
Pastorini J, Forstner MRJ, Martin RD, Melnick DJ. 1998. A re-examination of the phylogenetic position of Callimico (Primates) incorporating new mitochondrial DNA sequence data. J Mol Evol 47 (1): 32-41.

Perelman P, Johnson WE, Roos C, Seuánez HN, Horvath JE, Moreira MAM, Kessing B, Pontius J, Roelke M, Rumpler Y, Schneider MPC, Silva A, O'Brien SJO, Pecon-Slattery J. 2011. A molecular phylogeny of living primates. PLoS Genet 7(3): e1001342.

Peres CA. 1992. Prey-capture benefits in a mixed-species group of Amazonian tamarins, Saguinus fuscicollis and S. mystax. Behav Ecol Sociobiol 31(5): 339-347.

Peres CA. 1993. Diet and feeding ecology of Saddle-back (Saguinus fuscicollis) and Moustached (S. mystax) Tamarins in an Amazonian terra firme forest. J Zool 230: 567-592.

Peres CA. 1994. Structure and spatial organization of an Amazonian terra firme forest primate community. J Trop Ecol 9 (3): 259-276.

Peres CA. 1997. Primate community structure at twenty Western Amazonian flooded and unflooded forests. J Trop Ecol 13 (3): 381-405.

Pike AVL, Maitland DP. 2004. Scaling of bird claws. J Zool 262: 73-81.

Porter LM, Garber PA. 2004. Goeldi's monkeys: A primate paradox? Evol Anthropol 13: $104-115$.

Porter LM, Garber PA. 2010. Mycophagy and its influence on habitat use and ranging patterns in Callimico goeldii. Am J Phys Anthropol 142: 468-475.

Porter LM, Garber PA, Nacimento E. 2009. Exudates as a fallback food for Callimico goeldii. Am J Primatol 71(2): 120-129.

Porter LM, Sterr SM, Garber PA. 2007. Habitat use and ranging behavior of Callimico goeldii. Int J Primatol 28 (5): 1035-1058.

Porter LM. 2001. Dietary differences among sympatric callitrichinae in Northern Bolivia: Callimico goeldii, Saguinus fuscicollis and S. labiatus. Int J Primatol 22 (6): 961-993. 
Porter LM. 2004. Forest use and activity patterns of Callimico goeldii in comparison to two sympatric tamarins, Saguinus fuscicollis and Saguinus labiatus. Am J Phys Anthropol 124(2): 139-153.

Poveda K, Sanchez-Palomino P. 2004. Habitat use by the White-Footed Tamarin, Saguinus leucopus: A comparison between a forest-dwelling group and an urban group in Mariquita, Colombia. Neotrop Primates 12 (1): 6-9.

Raboy BE, Canale GR, Dietz JM. 2008. Ecology of Callithrix kuhlii and a review of Eastern Brazilian marmosets. Int J Primatol 29: 449-467.

Raboy BE, Dietz JM. 2004. Diet, foraging, and use of space in wild Golden-Headed Lion Tamarins. Am J Primatol 63: 1-15.

Rasband WS. 2009. ImageJ. U.S. National Institute of Health, Bethesda, Maryland, USA. http://rsb.info.nih.gov/ij/

Regan BC, Julliot C, Simmen B, Viénot F, Charles-Dominique P, Mollon JD. 2001. Fruits, foliage and the evolution of primate colour vision. Philos Trans Roy Soc Lond B Biol Sci 356: 229-283.

Rehg JA. 2009. Ranging patterns of Callimico goeldii in a mixed species group. In: Ford SM. et al. (Eds.) The Smallest Anthropoids, Developments in Primatology: Progress and Prospects. Springer, NY, USA

Ribas SC, Velloso ALR, Teixeira-Filho P, Rocha-Barbosa O, Evangelista H, Santos EA. 2004. Structure of claws and toes of two tropidurid lizard species of Restinga from Southeastern Brazil: adaptations to the vertical use of the habitat. Rev Chil Hist Nat 77: 599606.

Rosenberg HI, Rose R. 1999. Volar adhesive pads of the feathertail glider, Acrobates pygmaeus (Marsupialia; Acrobatidae). Can J Zool 77: 233-248. 
Rosenberger AL. 1992. Evolution of feeding niches in New World monkeys. Am J Phys Anthropol 88: 525-562.

Rylands AB, Mittermeier RA, Coimbra-Filho AF, Heymann EW, de la Torre S, de Sousa e Silva J, Kierulff MCM, Noronha MA, Röhe F. 2008. Marmosets and tamarins: Pocket identification guide. Conservation International, Bogotá, Colombia.

Rylands AB, Mittermeier RA, Silva JS. 2012. Neotropical primates: taxonomy and recently described species and subspecies. Int Zoo Yb 46: 11-24.

Rylands AB, Mittermeier RA. 2009. The diversity of the New World primates (Platyrrhini): An annotated taxonomy. In: Garber PA et al. (Eds) South American Primates, Developments in Primatology: Progress and Prospects. Springer, NY, USA. p 23-54.

Rylands AB, Schneider H, Langguth A, Mittermeier RA, Groves CP, Rodríguez L. 2000. An assessment of the diversity of New World Primates. Neotrop Prim 8: 61-93.

Schmidt M. 2005. Hindlimb proportions and kinematics: are small primates different from other small mammals? J Exp Biol 208: 3367-3383.

Schmidt M. 2008. Forelimb proportions and kinematics: how are small primates different from other small mammals? J Exp Biol 211: 3775-3789.

Schmitt D, Lemelin P. 2004. Locomotor mechanics of the Slender Loris (Loris tardigradus). J Hum Evol 47: 85-94.

Schmitt D. 2003. Evolutionary implications of the unusual walking mechanics of the Common Marmoset (C. jacchus). Am J Phys Anthropol 122: 28-37.

Shoshani J, Groves CP, Simons EL, Gunnell GF. 1996. Primate phylogeny: Morphological vs molecular results. Mol Phylogenet Evol 5 (1): 102-154.

Smith AC. 1997. Comparative ecology of Saddleback (Saguinus fuscicollis) and Moustached (Saguinus mystax) tamarins. PhD Thesis, University of Reading, UK. 
Smith AC. 2010. Exudativory in primates: interspecific patterns. In: Burrows, A., Nash, L. (Eds.). The Evolution of Exudativory in Primates. Developments in Primatology: Progress and Prospects. Springer, NY, USA. p 45-87.

Soligo C, Martin RD. 2006. Adaptive origins of primates revisited. J Hum Evol 50: 414430.

Soligo C, Müller AE. 1999. Nails and claws in primate evolution. J Hum Evol 36, $97-$ 114.

Stephenson IR, Bearder SK, Donati G, Karlsson J. 2010. A guide to galago diversity: Getting a grip on how best to chew gum. In: Burrows A, Nash L. (Eds). The Evolution of Exudativory in Primates, Developments in Primatology: Progress and Prospects. Springer, NY, USA. p 235-255.

Sussman RW, Kinzey WG. 1984. The ecological role of the Callitrichidae: A review. Am J Phys Anthropol 64: 419-449.

Thorndike EE. 1968. A microscopic study of the marmoset claw and nail. Am J Phys Anthropol (28): 247-262.

Tulli MJ, Cruz FB, Herrel A, Vanhooydonck B, Abdala V. 2009. The interplay between claw morphology and microhabitat use in neotropical iguanian lizards. Zoology 112: 379-392.

Van Valkenburgh B. 1987. Skeletal indicators of locomotor behavior in living and extinct carnivores. J Vert Paleo (7): 162-182.

Van Roosmalen MG, Van Roosmalen T. 2003. The description of a new marmoset genus, Callibella (Callitrichinae, Primates), including its molecular phylogenetic status. Neotrop Prim 11: $1-10$.

Veracini C. 2009. Habitat use and ranging behavior of the Silvery Marmoset (Mico argentatus) at Caxiuanã National Forest (Eastern Brazilian Amazonia). In: Ford SM. et al. 
(Eds.) The Smallest Anthropoids, Developments in Primatology: Progress and Prospects. Springer, NY, USA

Vinyard CJ, Wall CE, Williams SH, Mork AL, Armfield BA, de Oliveira Melo LC, Valenca-Montenegro MM, Valle YBM, de Oliveira MAB, Lucas PW, Schmitt D, Taylor AB, Hylander WL. 2009. The evolutionary morphology of tree gouging in marmosets. In: Ford SM et al. (Eds.) The Smallest Anthropoids, Developments in Primatology: Progress and Prospects. Springer, NY, USA.

Wright KA. 2007. The relationship between locomotor behavior and limb morphology in brown (Cebus apella) and weeper (Cebus olivaceus) capuchins. Am J Primatol 69 (7): 736756.

Yépez P, de la Torre S, Snowdon CT. 2005. Interpopulation differences in exudate feeding of Pygmy Marmosets in Ecuadorian Amazonia. Am J Primatol 66: 145-158.

Yoneda M. 1984a. Comparative studies on vertical separation, foraging behavior and traveling mode of Saddle-backed Tamarins (Saguinus fuscicollis) and Red-chested Moustached Tamarins (Saguinus labiatus) in Northern Bolivia. Primates 25 (4): 414-422.

Yoneda M. 1984b. Ecological study of the Saddle Backed Tamarin (Saguinus fuscicollis) in Northern Bolivia. Primates 25 (1): 1-12.

Youlatos D. 1999a. Positional behavior of Cebuella pygmaea in Yasuni National Park, Ecuador. Primates 40 (4): 543-550.

Youlatos D. 1999b. Comparative locomotion of six sympatric primates in Ecuador. Annales des Sciences Naturelles 20 (4): 161-168.

Youlatos D. 2009. Locomotion, postures, and habitat use by pygmy marmosets (Cebuella pygmaea). In: Ford SM et al. (Eds.) The Smallest Anthropoids, Developments in Primatology: Progress and Prospects. Springer, NY, USA. 
1

2

3

4

5

6

7

8

9

10

11

12

13

14

15

16

17

18

19

20

21

22

23

24

25

26

27

28

29

30

31

32

33

34

35

36

37

38

39

40

41

42

43

44

45

46

47

48

49

50

51

52

53

54

55

56

57

58

59

60

Young JW. 2009. Substrate determines asymmetrical gait dynamics in marmosets (Callithrix jacchus) and squirrel monkeys (Saimiri boliviensis). Am J Phys Anthropol 138: $403-420$.

Zani PA. 2000. The comparative evolution of lizard claw and toe morphology and clinging performance. J Evol Biol 13: 316-325.

John Wiley \& Sons, Inc. 


\section{TABLES}

Table 1: Museum specimens examined (species and numbers) and species abbreviations used in text and in figures.

Table 2: Values (average (s.e.) n) calculated from literature for percentage of diet represented by different nutritional sources, locomotor modes (\% locomotion observations), and support use ( $\%$ foraging observations) in 20 species of callitrichid.

Table 3: Head-body lengths, palmar and plantar ridge densities, tegula curvatures and hand and feet measurements relative to head-body length made from museum specimens of 25 species of callitrichid.

Table 4: Summary data for morphological parameters at genus level. Statistics for comparison between genera using ANOVA (unless otherwise indicated: * = Kruskal-Wallis).

Table 5: Species-level correlation statistics between HBL, body dimensions and various aspects of ecology in callitrichids $(* \log -\log$ relationships; **arcsin-transformed data) 


\section{FIGURE LEGENDS}

Figure 1: Boxplots of palmar and plantar ridge density in six genera of callitrichid: the marmosets (Mico, Callithrix, Cebuella), Callimico and tamarins (Leontopithecus and Saguinus). Statistics in text.

Figure 2: Relationships between vertical support foraging and (A) proportional foot length and (B) tegula curvature. Statistics in text. Genera symbols $\square$ Callimico $\bigcirc$ Callithrix $\triangle$ Cebuella $\diamond$ Leontopithecus Mico Saguinus. Species abbreviations as in Table 1.

Figure 3: Genus-level relationships between exudate consumption and (A) palmar ridge density and (B) plantar ridge density. Statistics in text. Genera symbols as Figure 2, species abbreviations as in Table 1.

John Wiley \& Sons, Inc. 
Table 1: Museum specimens examined (species and numbers) and species

abbreviations used in text and in figures.

Common name
Goeldii's monkey
Buffy-tufted marmoset
Buffy-headed marmoset
Common marmoset
Black-tufted marmoset
Pygmy marmoset
Golden-headed lion tamarin
Golden lion tamarin
Silvery marmoset
Gold-and-white marmoset
Black-and-white tassel-ear marmoset
Golden-white bare-ear marmoset
Black-tailed marmoset
Pied tamarin
Saddleback tamarin
Geoffroy's tamarin
Red-bellied tamarin
White-footed tamarin
Martin's tamarin
Golden-handed tamarin
Moustached tamarin
Black-handed tamarin
Black-mantled tamarin
Cottontop tamarin

Common name

Scientific name

Callimico goeldii

Callithrix aurita

Callithrix flaviceps

Callithrix jacchus

Callithrix penicillata

Cebuella pygmaea

Leontopithecus chrysomelas

Leontopithecus rosalia

Mico argentata

Mico chrysoleucus

Mico humeralifer

Mico leucippe

Mico melanurus

Saguinus bicolor

Saguinus fuscicollis

Saguinus geoffroyi

Saguinus labiatus

Saguinus leucopus

Saguinus martinsi

Saguinus midas

Saguinus mystax

Saguinus niger

Saguinus nigricollis

Saguinus oedipus

$\begin{array}{lll}\text { Authority } & \text { Abbreviation } & \mathrm{n} \\ \text { Thomas, 1901 } & \text { Cmg } & 5 \\ \text { Geoffroy, 1812 } & \text { Cau } & 1 \\ \text { Thomas, 1903 } & \text { Cfl } & 3 \\ \text { Linnaeus, 1758 } & \text { Cja } & 17 \\ \text { Geoffroy, 1812 } & \text { Cpe } & 23 \\ \text { Spix, 1823 } & \text { Ceb } & 11 \\ \text { Kuhl, 1812 } & \text { Lcr } & 1 \\ \text { Linnaeus, 1766 } & \text { Lro } & 6 \\ \text { Linnaeus, 1766 } & \text { Mar } & 3 \\ \text { Wagner, 1842 } & \text { Mcr } & 2 \\ \text { Geoffroy, 1812 } & \text { Mhu } & 4 \\ \text { Thomas, 1922 } & \text { Mle } & 1 \\ \text { Geoffroy, 1812 } & \text { Mme } & 6 \\ \text { Spix, 1823 } & \text { Sbi } & 2 \\ \text { Spix, 1823 } & \text { Sfu } & 59 \\ \text { Pucheran, 1845 } & \text { Sge } & 4 \\ \text { Geoffroy, 1812 } & \text { Sla } & 11 \\ \text { Günther, 1877 } & \text { Sle } & 2 \\ \text { Thomas, 1912 } & \text { Sma } & 1 \\ \text { Linnaeus, 1758 } & \text { Smi } & 24 \\ \text { Spix, 1803 } & \text { Smy } & 20 \\ \text { Geoffroy, 1803 } & \text { Snr } & 11 \\ \text { Spix, 1823 } & \text { Sns } & 13 \\ \text { Linnaeus, 1758 } & \text { Soe } & 3\end{array}$


Table 2: Values (average (s.e.) n) calculated from literature for percentage of diet represented by different nutritional sources, locomotory modes (\% locomotion observations), and support use (\% foraging observations) in 20 species of callitrichid.

\begin{tabular}{|c|c|c|c|c|c|c|c|}
\hline \multirow[t]{2}{*}{ Species } & \multicolumn{3}{|c|}{ Percentage of diet represented by: } & \multirow{2}{*}{$\begin{array}{l}\% \text { vertical } \\
\text { support use } \\
\text { (foraging) }\end{array}$} & \multicolumn{2}{|c|}{ Percentage locomotion: } & \multirow[t]{2}{*}{ References } \\
\hline & Fruit & Animal & Exudates & & Scansorial & Leaping & \\
\hline Cmg & $33(4.1) 8$ & $24(5.9) 8$ & $7(2.0) 8$ & $42(7.5) 2$ & $15(0.6) 3$ & $55(-) 1$ & $6,11,19,29,31,34,38,48,52,53,56$ \\
\hline $\mathrm{Cau}$ & $23(7.0) 4$ & $29(4.1) 4$ & $42(7.4) 6$ & - & - & - & $9,11,24,41 b, 49,27,52,58$ \\
\hline$C f l$ & $5(2.4) 5$ & $20(2.0) 6$ & $65(10.3) 7$ & - & - & - & $8,11,17,24,49,52,56$ \\
\hline Cja & $24(2.4) 6$ & $18(2.6) 7$ & $55(3.0) 9$ & - & - & - & $9,11,17,21,23,40,43,44,49,50,52,56$ \\
\hline Cpe & - & $29(-) 1$ & $57(13.5) 3$ & - & - & - & $2,11,30$ \\
\hline $\mathrm{Ceb}$ & - & $22(11.0) 2$ & $69(2.1) 2$ & $60(37) 2$ & $36(6.3) 3$ & $37(-) 1$ & $6,8,9,11,13,22,55,38,39,44,45,50,52$ \\
\hline Lcr & $82(-) 1$ & $14(-) 1$ & $7(-) 1$ & - & - & - & $8,9,11,41 \mathrm{a}$ \\
\hline Lro & $77(7.7) 3$ & $15(0.4) 4$ & $\mathbf{1}(0.6) 4$ & - & - & - & $8,9,56,11,18,21,36,44,46$ \\
\hline Mar & $36(-) 1$ & $5(-) 1$ & $59(-) 1$ & - & - & - & $6,24,54$ \\
\hline Mhu & - & - & $27(-) 1$ & - & - & - & $6,9,52$ \\
\hline$S b i$ & $39(-) 1$ & $59(-) 1$ & $1(-) 1$ & - & - & - & 7 \\
\hline Sfu & $\mathbf{5 9}(5.6) 10$ & $23(6.4) 10$ & $14(2.4) 10$ & $33(-) 1$ & $16(1.4) 3$ & $32(8.8) 2$ & $4 \mathrm{~b}, 5,6,8,9,10,11,12,13,14,16,25,26,29,31,34,37,38,44,47,53,57$ \\
\hline Sge & $44(6.2) 3$ & $31(8.9) 3$ & $20(5.2) 3$ & $13(-) 1$ & - & $4(-) 1$ & $1,9,11,38,57$ \\
\hline Sla & $\mathbf{6 8}(8.1) 4$ & $11(-) 2$ & $11(2.0) 3$ & $19(-) 1$ & $6(0.5) 2$ & $8(0.2) 2$ & $4 a, 8,11,25,29,53,31,32,34,37,38,52$ \\
\hline Sle & $83(-) 1$ & $12(-) 1$ & $\mathbf{0}(-) 1$ & - & - & - & 35 \\
\hline Smi & $\mathbf{5 6}(8.5) 2$ & $31(-) 1$ & $5(-) 1$ & - & - & - & $6,9,32,33,45$ \\
\hline Smy & $54(5.6) 8$ & $33(7.2) 9$ & $8(2.5) 9$ & $13(4.2) 4$ & $3(0.4) 2$ & $10(0.9) 2$ & $5,8,9,10,11,12,13,15,16,20,25,26,37,38,44,47,52,57,58$ \\
\hline Snr & $84(6.9) 3$ & $7(1.5) 3$ & $13(10.4) 2$ & - & - & - & $11,28,42,57$ \\
\hline Soe & $38(-) 1$ & $39(-) 1$ & $14(-) 1$ & - & $17(-) 1$ & - & $3,9,21,52$ \\
\hline Str & $40(21.5) 2$ & $48(26.5) 2$ & $12(-) 1$ & - & $16(-) 1$ & $18(-) 1$ & $38,45,57$ \\
\hline
\end{tabular}


Table 3: Head-body lengths, palmar and plantar ridge densities, tegula curvatures and hand and feet measurements relative to head-body

length made from museum specimens of 25 species of callitrichid.

Lengths as proportion of HBL

\begin{tabular}{|c|c|c|c|c|c|c|}
\hline \multirow{2}{*}{$\begin{array}{l}\text { Palmar ridge } \\
\text { density } \\
\text { (ridges } / \mathrm{mm} \text { ) }\end{array}$} & \multirow{2}{*}{$\begin{array}{l}\text { Plantar ridge } \\
\text { density } \\
\text { (ridges } / \mathrm{mm} \text { ) }\end{array}$} & \multirow{2}{*}{$\begin{array}{l}\text { Tegula } \\
\text { curvature }\left({ }^{\circ}\right)\end{array}$} & \multicolumn{4}{|c|}{ Lengths as proportion of HBL } \\
\hline & & & Hand & Finger & Foot & Toe \\
\hline $4.0(0.10) 5$ & $3.7(0.20) 5$ & $\mathbf{1 3 8}(6.9) 4$ & $\mathbf{0 . 1 9}(0.014) 5$ & $\mathbf{0 . 0 6 3}(0.005) 5$ & $\mathbf{0 . 2 2}(0.014) 5$ & $\mathbf{0 . 0 6 9}(0.004) 5$ \\
\hline $3.9(-) 1$ & $4.7(-) 1$ & $103(-) 1$ & $0.14(-) 1$ & $0.056(-) 1$ & $0.21(-) 1$ & $0.068(-) 1$ \\
\hline $4.1(0.70) 2$ & $4.3(0.60) 2$ & $116(3.9) 2$ & $\mathbf{0 . 1 6}(0.007) 3$ & $\mathbf{0 . 0 5 6}(0.004) 3$ & $0.23(0.013) 3$ & $\mathbf{0 . 0 7 0}(0.002) 3$ \\
\hline $5.3(0.13) 16$ & $4.8(0.14) 16$ & $139(3.8) 11$ & $\mathbf{0 . 1 6}(0.004) 17$ & $\mathbf{0 . 0 5 9}(0.002) 17$ & $\mathbf{0 . 2 2}(0.006) 17$ & $\mathbf{0 . 0 7 0}(0.003) 17$ \\
\hline $5.3(0.09) 18$ & $4.8(0.09) 18$ & $135(2.7) 15$ & $\mathbf{0 . 1 6}(0.005) 23$ & $\mathbf{0 . 0 6 0}(0.002) 23$ & $\mathbf{0 . 2 2}(0.005) 23$ & $\mathbf{0 . 0 7 0}(0.002) 23$ \\
\hline $5.2(0.14) 11$ & $\mathbf{5 . 0}(0.17) 11$ & $144(3.8) 5$ & $\mathbf{0 . 1 8}(0.007) 11$ & $\mathbf{0 . 0 7 2}(0.003) 11$ & $\mathbf{0 . 2 3}(0.008) 11$ & $\mathbf{0 . 0 7 7}(0.004) 11$ \\
\hline $4.3(-) 1$ & $5.1(-) 1$ & $145(-) 1$ & $0.29(-) 1$ & $0.098(-) 1$ & $0.26(-) 1$ & $0.082(-) 1$ \\
\hline $4.5(0.15) 6$ & $4.2(0.12) 6$ & - & $\mathbf{0 . 2 0}(0.013) 6$ & $\mathbf{0 . 0 7 1}(0.003) 6$ & $0.23(0.013) 6$ & $\mathbf{0 . 0 7 5}(0.006) 6$ \\
\hline $5.1(0.65) 3$ & $5.1(0.17) 3$ & $133(3.0) 2$ & $\mathbf{0 . 1 7}(0.012) 3$ & $\mathbf{0 . 0 5 6}(0.004) 3$ & $0.22(0.015) 3$ & $\mathbf{0 . 0 7 3}(0.007) 3$ \\
\hline $4.8(0.35) 2$ & $5.2(0.10) 2$ & $137(-) 1$ & $0.21(0.025) 2$ & $\mathbf{0 . 0 7 6}(0.007) 2$ & $\mathbf{0 . 2 8}(0.067) 2$ & $\mathbf{0 . 0 7 9}(0.017) 2$ \\
\hline $5.2(0.19) 4$ & $4.7(0.11) 4$ & $145(4.0) 3$ & $\mathbf{0 . 1 6}(0.004) 4$ & $\mathbf{0 . 0 5 1}(0.001) 4$ & $\mathbf{0 . 2 1}(0.015) 4$ & $\mathbf{0 . 0 6 7}(0.004) 4$ \\
\hline $4.9(-) 1$ & $5.5(-) 1$ & $137(-) 1$ & $0.16(-) 1$ & $0.062(-) 1$ & & \\
\hline $5.3(0.41) 4$ & $4.8(0.26) 4$ & $\mathbf{1 4 7}(9.5) 3$ & $\mathbf{0 . 1 6}(0.004) 6$ & $\mathbf{0 . 0 5 9}(0.003) 6$ & $0.21(0.006) 6$ & $\mathbf{0 . 0 6 2}(0.004) 5$ \\
\hline $6.3(0.85) 2$ & $4.9(0.25) 2$ & $118(1.1) 2$ & $\mathbf{0 . 1 6}(0.004) 2$ & $\mathbf{0 . 0 6 3}(0.007) 2$ & $\mathbf{0 . 2 1}(0.038) 2$ & $\mathbf{0 . 0 6 9}(0.011) 2$ \\
\hline $4.7(0.07) 43$ & $4.2(0.06) 14$ & $134(2.2) 36$ & $\mathbf{0 . 1 7}(0.003) 59$ & $\mathbf{0 . 0 6 0}(0.001) 63$ & $\mathbf{0 . 2 1}(0.003) 59$ & $\mathbf{0 . 0 6 5}(0.001) 59$ \\
\hline $5.1(0.19) 5$ & $4.3(0.23) 15$ & $\mathbf{1 2 9}(9.3) 2$ & $\mathbf{0 . 1 6}(0.012) 4$ & $\mathbf{0 . 0 5 6}(0.005) 5$ & $0.21(0.018) 4$ & $\mathbf{0 . 0 6 4}(0.007) 5$ \\
\hline $4.7(0.19) 9$ & $4.9(0.20) 16$ & $133(5.3) 7$ & $\mathbf{0 . 1 6}(0.007) 11$ & $\mathbf{0 . 0 5 9}(0.004) 11$ & $\mathbf{0 . 1 9}(0.011) 11$ & $\mathbf{0 . 0 5 7}(0.004) 11$ \\
\hline $4.2(0.35) 2$ & $3.7(0.10) 17$ & $147(7.5) 2$ & $\mathbf{0 . 1 6}(0.004) 2$ & $\mathbf{0 . 0 5 4}(0.005) 2$ & $\mathbf{0 . 1 9}(0.017) 2$ & $\mathbf{0 . 0 6 6}(0.001) 2$ \\
\hline $\mathbf{4 . 6 ( - )} 1$ & $4.1(-) 18$ & $146(-) 1$ & $0.23(-) 1$ & $0.081(-) 1$ & $0.21(-) 1$ & $0.068(-) 1$ \\
\hline $4.9(0.13) 15$ & $4.7(0.15) 19$ & $120(4.8) 13$ & $\mathbf{0 . 1 7}(0.009) 24$ & $\mathbf{0 . 0 5 7}(0.003) 25$ & $0.19(0.004) 24$ & $\mathbf{0 . 0 6 1}(0.001) 25$ \\
\hline $4.8(0.10) 18$ & $4.5(0.14) 20$ & $110(12.5) 2$ & $\mathbf{0 . 1 5}(0.005) 20$ & $\mathbf{0 . 0 5 5}(0.002) 24$ & $\mathbf{0 . 2 0}(0.005) 20$ & $\mathbf{0 . 0 5 3}(0.003) 20$ \\
\hline $4.9(0.14) 10$ & $4.5(0.17) 21$ & $123(4.9) 10$ & $\mathbf{0 . 1 6}(0.006) 11$ & $\mathbf{0 . 0 5 9}(0.004) 11$ & $\mathbf{0 . 2 0}(0.007) 11$ & $\mathbf{0 . 0 6 3}(0.003) 11$ \\
\hline $4.7(0.12) 12$ & $4.2(0.16) 22$ & $135(4.0) 7$ & $\mathbf{0 . 1 6}(0.006) 13$ & $\mathbf{0 . 0 5 9}(0.002) 13$ & $\mathbf{0 . 1 8}(0.009) 13$ & $\mathbf{0 . 0 5 4}(0.004) 13$ \\
\hline $3.8(0.10) 2$ & $4.4(0.45) 23$ & - & $\mathbf{0 . 1 6}(0.004) 3$ & $\mathbf{0 . 0 6 2}(0.005) 3$ & $0.26(0.025) 3$ & $\mathbf{0 . 0 6 9}(0.006) 3$ \\
\hline $4.6(0.25) 2$ & $4.4(0.15) 24$ & $123(7.2) 2$ & $\mathbf{0 . 1 7}(0.013) 2$ & $\mathbf{0 . 0 7 7}(0.008) 2$ & $\mathbf{0 . 2 2}(0.008) 2$ & $\mathbf{0 . 0 7 1}(0.009) 2$ \\
\hline
\end{tabular}


Table 4: Summary data for morphological parameters at genus level. Statistics for comparison between genera using ANOVA (unless otherwise indicated: * = Kruskal-Wallis).

\begin{tabular}{|c|c|c|c|c|c|c|c|c|}
\hline & & & & & & & Comparis & \\
\hline & Callimico & Callithrix & Cebuella & Leontopithecus & Mico & Saguinus & Statistic & $\mathrm{p}<$ \\
\hline Size class & Large & Medium & Small & Large & Medium & Large & & \\
\hline Head-body length (mm) & $246(20) 5$ & 227 (4) 37 & $142(4) 11$ & $272(10) 7$ & $231(7) 15$ & $260(2) 120$ & $76.93^{*}$ & 0.001 \\
\hline Palmar ridge density (no/mm) & $\mathbf{4 . 0 0}(0.16) 5$ & $\mathbf{5 . 1 9}(0.10) 37$ & $\mathbf{5 . 2 3}(0.14) 11$ & $\mathbf{4 . 4 4}(0.13) 7$ & $\mathbf{5 . 2 6}(0.21) 15$ & $4.74(0.04) 120$ & 9.88 & 0.001 \\
\hline Plantar ridge density $(\mathrm{no} / \mathrm{mm})$ & $3.66(0.20) 5$ & $\mathbf{4 . 8 1}(0.08) 37$ & $\mathbf{5 . 0 3}(0.17) 11$ & $\mathbf{4 . 2 9}(0.17) 7$ & $4.93(0.10) 15$ & $4.39(0.05) 120$ & 9.68 & 0.001 \\
\hline Tegula curvature $\left({ }^{\circ}\right)$ & $138.1(6.88) 4$ & $\mathbf{1 3 4 . 0}(2.50) 29$ & $\mathbf{1 4 4 . 5}(3.76) 5$ & $145.4(-) 1$ & $\mathbf{1 3 9 . 6}(3.61) 11$ & $\mathbf{1 2 9 . 7}(1.66) 83$ & 2.78 & 0.05 \\
\hline Hand length/HBL & $\mathbf{0 . 1 8}(0.014) 5$ & $\mathbf{0 . 1 6}(0.003) 37$ & $\mathbf{0 . 1 8}(0.006) 11$ & $\mathbf{0 . 2 1}(0.02) 7$ & $\mathbf{0 . 1 7}(0.005) 16$ & $\mathbf{0 . 1 6}(0.002) 152$ & 6.57 & 0.001 \\
\hline Foot length/HBL & $\mathbf{0 . 2 2}(0.014) 5$ & $\mathbf{0 . 2 2}(0.004) 44$ & $\mathbf{0 . 2 3}(0.008) 11$ & $\mathbf{0 . 2 3}(0.01) 7$ & $\mathbf{0 . 2 2}(0.01) 15$ & $\mathbf{0 . 2 0}(0.002) 152$ & 6.89 & 0.001 \\
\hline Finger length/HBL & $\mathbf{0 . 0 6 3}(0.005) 5$ & $\mathbf{0 . 0 5 9}(0.001) 44$ & $\mathbf{0 . 0 7 2}(0.003) 11$ & $\mathbf{0 . 0 7 5}(0.005) 7$ & $\mathbf{0 . 0 5 9}(0.002) 16$ & $\mathbf{0 . 0 5 8}(0.001) 164$ & $22.70^{*}$ & 0.001 \\
\hline Toe length/HBL & $\mathbf{0 . 0 6 9}(0.004) 5$ & $\mathbf{0 . 0 7 0}(0.002) 44$ & $\mathbf{0 . 0 7 7}(0.004) 11$ & $\mathbf{0 . 0 7 6}(0.005) 7$ & $\mathbf{0 . 0 6 8}(0.003) 15$ & $\mathbf{0 . 0 6 1}(0.001) 154$ & 8.38 & 0.001 \\
\hline
\end{tabular}


Table 5: Species-level correlation statistics between HBL, body dimensions and various aspects of ecology in callitrichids (*log-log relationships; **arcsin-transformed data)

$\begin{array}{lllll}\text { HBL vs. } & \mathrm{R} & \mathrm{df} & \mathrm{p}< & \text { Equation } \\ \text { Hand length* } & 0.56 & 24 & 0.01 & \mathrm{y}=0.68 \mathrm{x}-0.007 \\ \text { Finger length* } & 0.50 & 24 & 0.01 & \mathrm{y}=0.72 \mathrm{x}-0.496 \\ \text { Foot length* } & 0.73 & 24 & 0.001 & \mathrm{y}=0.65 \mathrm{x}+0.164 \\ \text { Toe length* } & 0.41 & 24 & 0.05 & \mathrm{y}=0.62 \mathrm{x}-0.301 \\ \text { Palmar ridge density } & 0.38 & 24 & 0.06 & \mathrm{NS} \\ \text { Plantar ridge density } & 0.56 & 24 & 0.01 & \mathrm{y}=-0.008 \mathrm{x}+6.49 \\ \text { Tegulae (radians) } & 0.51 & 22 & 0.05 & \mathrm{y}=-0.003 \mathrm{x}+3.08 \\ & & & & \\ \text { Exudativory** } & 0.46 & 19 & 0.01 & \mathrm{y}=-0.005 \mathrm{x}+1.42 \\ \text { Scansorial activity** } & 0.91 & 7 & 0.01 & \mathrm{y}=-0.003 \mathrm{x}+0.76 \\ \text { Vertical supports** } & 0.84 & 5 & 0.05 & \mathrm{y}=-0.003 \mathrm{x}+1.01\end{array}$




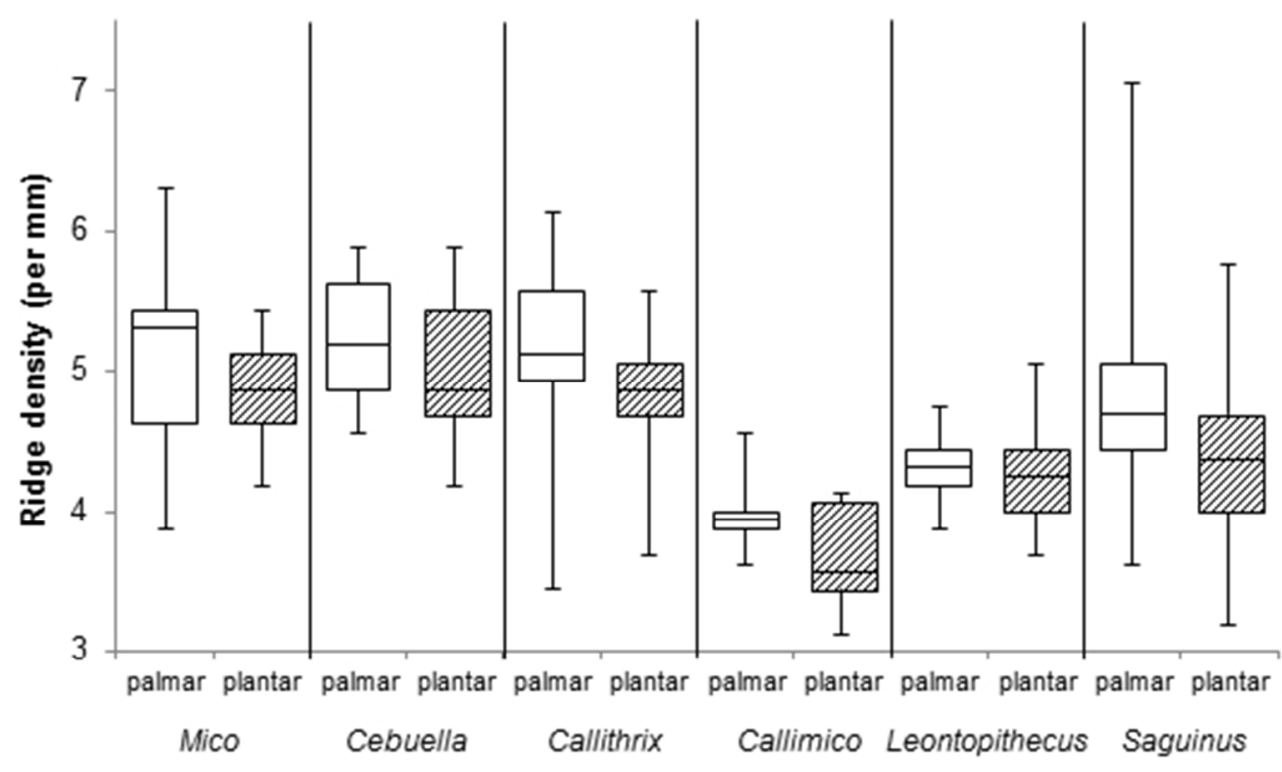

Fig. 1

$143 \times 91 \mathrm{~mm}(96 \times 96 \mathrm{DPI})$

John Wiley \& Sons, Inc. 


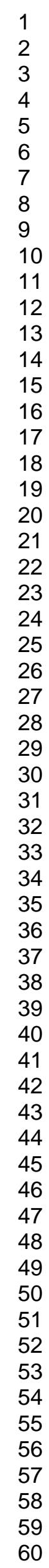
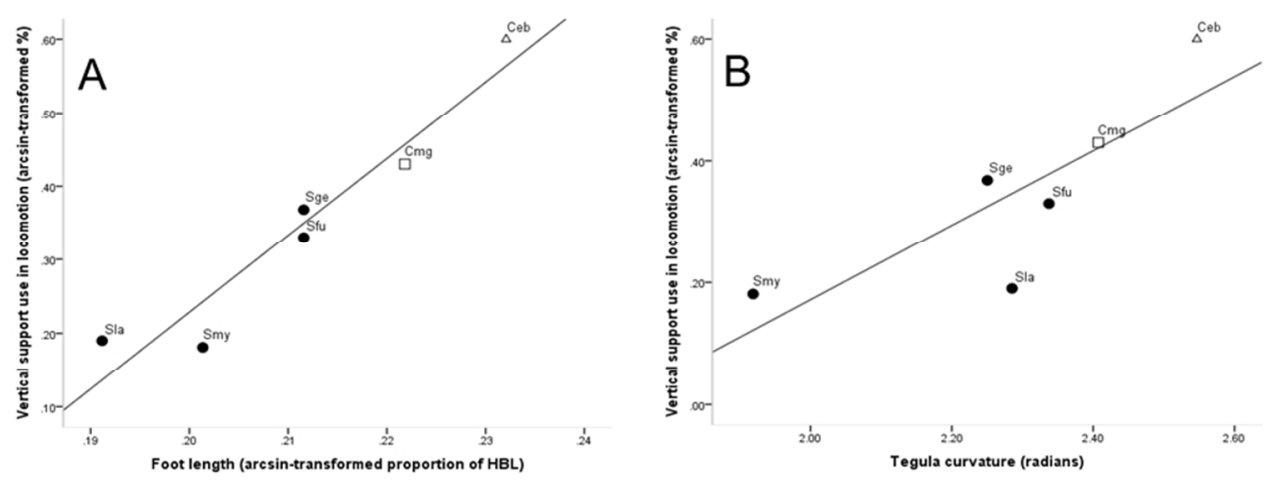

Fig. 2

$254 \times 100 \mathrm{~mm}$ (96 x 96 DPI)

John Wiley \& Sons, Inc. 


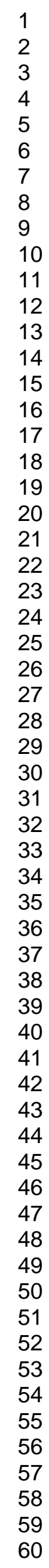
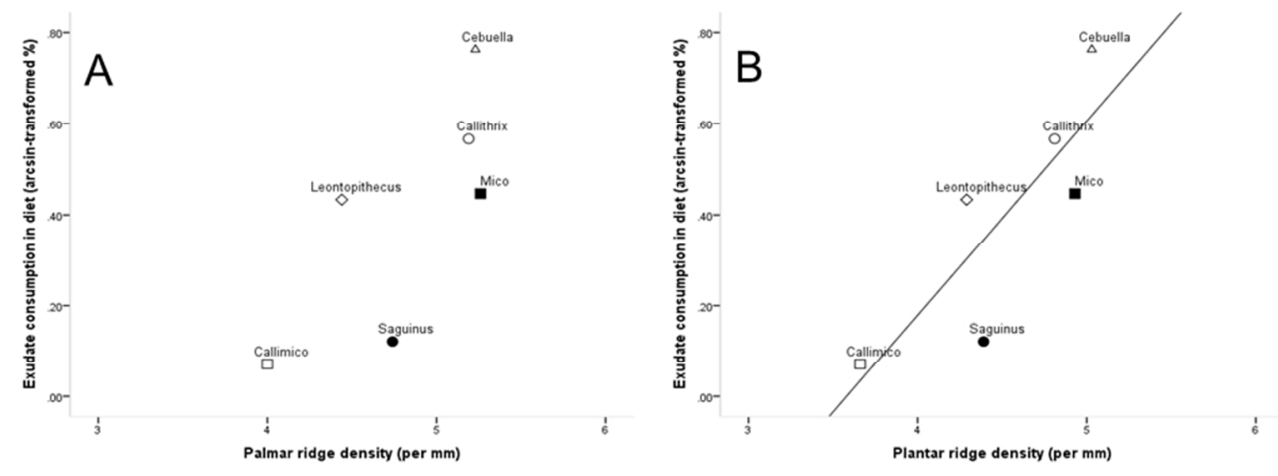

Fig. 3

$254 \times 93 \mathrm{~mm}$ (96 x 96 DPI)

John Wiley \& Sons, Inc. 